\title{
Immunologic hypo- or non-responder in natural dengue virus infection
}

\author{
Guey Chuen Perng ${ }^{1,2,3^{*}}$ and Kulkanya Chokephaibulkit ${ }^{4}$
}

\begin{abstract}
Serologically defined primary dengue virus infection and/or subsequent homologous serotype infection is known to be associated with less severe disease as compared with secondary subsequent heterologous serotype infection. In geographical locales of high dengue endemicity, almost all individuals in the population are infected at some point in time and should therefore are at high risk of secondary infection. Interestingly, dengue viremia in healthy blood donors whose sera apparently lack detectable levels of specific antibody to dengue viral antigens has been reported. The incidence rate of potential immunologic hypo- or non-responders following natural primary dengue virus infection in dengue endemic regions, who do become immune responders only after repeated exposure, has not been described. These are the patients who may be diagnosed as primary infection in the subsequent infection, but actually are secondary infection. This concept has important implications with regards to the hypothesis of immunological enhancement of dengue pathogenesis, which has largely been advanced based on empirical observations and/or from in vitro experimental assays. The fact that dengue naïve travelers can suffer from severe dengue upon primary exposure while visiting dengue endemic countries underscores one of the major problems in explaining the role of immune enhancement in the pathogenesis of severe dengue virus infection. This evidence suggests that the mechanism(s) leading to severe dengue may not be associated with pre-existing enhancing antibody. Consequently, we propose a new paradigm for dengue virus infection classification. These include a) patients with naïve primary infection, b) those that are serologically defined primary in dengue endemic zones and c) those who are serologically defined secondary dengue virus infection. We submit that clarity with regards to such definitions may help facilitate the delineation of the potential mechanisms of severe dengue virus infection.
\end{abstract}

Keywords: Nonresponder, Naïve, Flavivirus, Dengue fever, DHF

\section{Review}

Dengue is one of the most important vector-borne human diseases globally as well as a major public health burden and threat. There are four distinct viral serotypes, each one of them is capable of causing a wide spectrum of dengue manifestations including plasma leakage and shock with multi-organ failure. The resurgence of the dengue endemnicity has resulted from numerous oscillating environmental, social and economical factors. Two-fifths of the world's population is at risk of dengue virus infection, with approximately one-half million requiring hospitalization, with an

\footnotetext{
* Correspondence: gperng@mail.ncku.edu.tw

'Department of Microbiology and Immunology, Medical College, National

Cheng Kung University, Tainan 70101, Taiwan

${ }^{2}$ Center of Infectious Disease and Signaling Research, National Cheng Kung

University, Tainan 70101, Taiwan

Full list of author information is available at the end of the article
}

estimated 25,000 deaths annually, according to the WHO. Currently, there are no effective antiviral modalities and/or preventive vaccines available to combat or control dengue virus infection. The precise mechanism by which only a small percentage of dengue virus infected individuals progessing to severe dengue disease remains poorly understood.

The pathophysiology of severe dengue virus infection is very complex and may involve multiple factors. One of the factors believed to play a role in the pathogenesis of severe dengue disease is the presence of pre-existing dengue reactive antibody as available data from dengue epidemic countries have indicated that severe disease more frequently occurs during subsequent viral infections with a different dengue serotype [1,2], as defined by the standard serological test. However, recent results obtained from non-dengue endemic regions [3] and

\section{Biomed Central}


from travelers suggest that the frequency of severe dengue diseases during primary infection in immune-naive individuals is similar to that of heterologous secondary infections in endemic areas [4]. The immune enhancement theory is further put to question by the study by Libraty et al [5] which included a cohort study that revealed the lack of an association between maternal antibodies and development of severe dengue in infected infants. Collectively, the evidence suggests that as yet undefined factor(s) play a critical role in the development of severe dengue in naïve primary infection. We submit that the cause of severe pathology in truly naïve individuals infected by dengue virus may be distinguishable from that of serologically defined primary infection in dengue endemic zones.

According to the $\mathrm{WHO}$ guidelines, it is required that paired specimens from individual patients be simultaneously processed to clearly define the infection as primary or secondary in dengue endemic regions. But, very often, paired-sample collection is impractical in routine clinical practice. This limitation has led to the definition of primary and secondary infection in dengue endemic zones by the analysis of the ratio of IgM/IgG on a single sample; if the value is $>1.2$, then it is a primary infection, but if the value is $\leq 1.2$, it is noted as a secondary infection. Epidemiologically, serological surveillance studies

Table 1 DENV detection in blood donations collected in Puerto Rico in 2007

\begin{tabular}{|c|c|c|c|c|c|c|c|c|}
\hline \multirow[b]{2}{*}{ Unit } & \multicolumn{2}{|c|}{ S/CO by TMA* } & \multicolumn{2}{|c|}{ S/CO by eTMA } & \multicolumn{4}{|c|}{ CDC Testing } \\
\hline & Initial & $\overline{\text { Retest }}$ & Initial & $\overline{\text { Retest }}$ & Serotype & Viral load (Copies/ml) & $\mathrm{C} 6 / 36^{\#}$ & Anti-DENV IgM \\
\hline 1 & 27.75 & 38.99 & 87.16 & 88.52 & DENV-2 & $1.12 \times 109$ & Pos & Neg \\
\hline 2 & 32.34 & 33.30 & & & DENV-2 & $5.08 \times 108$ & Pos & Pos \\
\hline $3^{\&}$ & 33.30 & 37.38 & 91.10 & 83.09 & DENV-2 & $1.35 \times 108$ & Pos & Neg \\
\hline 4 & 37.66 & 39.16 & 87.13 & 89.32 & DENV-3 & $7.25 \times 107$ & Pos & Neg \\
\hline 5 & 40.29 & 27.03 & 82.29 & 92.04 & DENV-3 & $1.37 \times 107$ & Pos & Neg \\
\hline 6 & 32.73 & 35.03 & & & DENV-3 & $1.18 \times 107$ & Pos & Neg \\
\hline 7 & 33.91 & 32.87 & & & DENV-3 & $7.67 \times 106$ & Pos & Neg \\
\hline 8 & 31.97 & 30.59 & & & DENV-1 & $4.49 \times 106$ & Pos & Neg \\
\hline 9 & 19.14 & 13.94 & & & DENV-2 & $2.82 \times 106$ & Pos & Pos \\
\hline 10 & 33.10 & 38.68 & 87.86 & 89.91 & DENV-3 & $6.39 \times 105$ & Pos & Neg \\
\hline 11 & 31.25 & 33.56 & & & DENV-3 & $3.50 \times 105$ & Pos & Neg \\
\hline 12 & 5.68 & 20.55 & 29.48 & 21.59 & DENV-3 & $1.00 \times 105$ & Pos & Neg \\
\hline 13 & 34.81 & 37.21 & 76.16 & 32.72 & & $<103$ & Neg & Neg \\
\hline 14 & 23.38 & 31.07 & 31.25 & 31.18 & & $<103$ & Neg & Neg \\
\hline 15 & 14.23 & 23.26 & 28.59 & 3.28 & & $<103$ & Neg & Pos \\
\hline 16 & 13.14 & 25.77 & 29.26 & 12.51 & & $<103$ & Neg & Neg \\
\hline 17 & 11.51 & 5.63 & & & & $<103$ & $\mathrm{Neg}$ & Neg \\
\hline 18 & 8.17 & 16.58 & & & & $<103$ & Neg & Neg \\
\hline 19 & 6.64 & 8.91 & & & & $<103$ & Neg & Pos \\
\hline 20 & 5.06 & 4.12 & 29.96 & 8.61 & & $<103$ & Neg & Neg \\
\hline 21 & 3.37 & 4.95 & & & & $<103$ & Neg & Pos \\
\hline 22 & 2.95 & 25.28 & & & & $<103$ & Neg & Pos \\
\hline 23 & 8.20 & 1.40 & & & & $<103$ & Neg & Neg \\
\hline 24 & 4.46 & 0.01 & 24.80 & 0.06 & & $<103$ & Neg & Neg \\
\hline 25 & 1.02 & 2.29 & 28.01 & 0.01 & & $<103$ & Neg & Neg \\
\hline $26^{\%}$ & 0.45 & & 26.38 & 27.55 & & $<103$ & Neg & Neg \\
\hline $27^{\%}$ & 0.17 & & 26.18 & 30.99 & & $<103$ & Neg & Neg \\
\hline $28 \%$ & 0.30 & & 25.31 & 29.11 & & $<103$ & Neg & Neg \\
\hline $29 \%$ & 0.50 & & 24.34 & 17.85 & & $<103$ & Neg & Neg \\
\hline
\end{tabular}

${ }^{*}$ TMA reactive when the $\mathrm{S} / \mathrm{CO}$ ratio is 1.00 or greater. ${ }^{5}$ Serotype-specific, real-time RT-PCR. ${ }^{\prime \prime} \mathrm{C} 6 / 36=$ the mosquito cell line used for infectivity studies. ${ }^{8}$ Unit3 was involved in a transfusion transmission. ${ }^{\%}$ Four TMA nonreactive samples were eTMA reactive. Bold text indicates positive values. With permission from originally published in Transfusion 2012 Aug; 52(8):1657-66. 
have revealed that about 85 to $95 \%$ of school-aged children in endemic countries are positive for dengue IgG antibody [2,6,7]. Interestingly, a recent report [8] demonstrates that dengue viremia can exist in healthy blood donors whose sera apparently lack detectable levels of specific antibody to dengue virus (Table 1), and the incidence varies, ranging from $0.7 / 1000$ to $4.5 / 1000$, dependent upon season and year [9]. Thus, besides the use of the $\operatorname{IgM} / \operatorname{IgG}$ ratio, it is difficult at best to distinguish between primary and secondary infection. It is further complicated by the incidence of non-classical serologic responses, in which the ratio value is often slightly below 1.2. Such cases are very often arbitrarily assigned as secondary infection, and thus the definition has been called into question [10]. The fact that there exist asymptomatic dengue viremia positive but antibody undetectable individuals in dengue endemic geographical locales, presents an important challenge to the blood supply of that region [11-13]. Dengue inapparent infection has been documented in literature since 1939, in which volunteers intravenously received serum taken from an acute dengue patient, but no clinical symptoms were observed, and yet serum taken from this subject was able to infect a new healthy volunteer. Hence the term dengue inapparent infection was instituted [14]. Interestingly, it has been proposed that asymptomatic dengue cases may account for the introduction and spread of dengue viruses in non-endemic regions [15]. Consequently, the cumulative evidence suggests that asymptomatic viremia may have an important role in dengue transmission and warrant a more in depth investigation.

Within the context of diagnoses that are based on serological tests, it is important to note the results that have been recorded following routine vaccinations. The estimated frequency of immunologic non-responders among Hepatitis B vaccine and Venezuelan equine encephalitis (VEE) vaccine recipients is around 1-10\% [16-18] and about 18-26\% [19], respectively. However, the occurrence of such non-responders following natural Hepatitis B or VEE infection has not so far been investigated or documented. Furthermore, although the frequency of hypo- or nonresponders in natural dengue virus infection has never been explored, recent data accumulated from screening of healthy blood donors living in a dengue endemic zone suggest that the incidence ranges from 4.5 to 0.7 per 1000 donors [9]. In addition, extrapolation of cumulative data of seroconversion following monovalent or tetravalent dengue vaccine trials suggested that hypo- or nonresponders after a single dose of vaccine was found to be between 15 to 22\% (Figure 1), regardless where the trials are performed. Epidemiologically, the prevalence of IgM and/or IgG negative individuals reported in serological studies conducted in dengue endemic

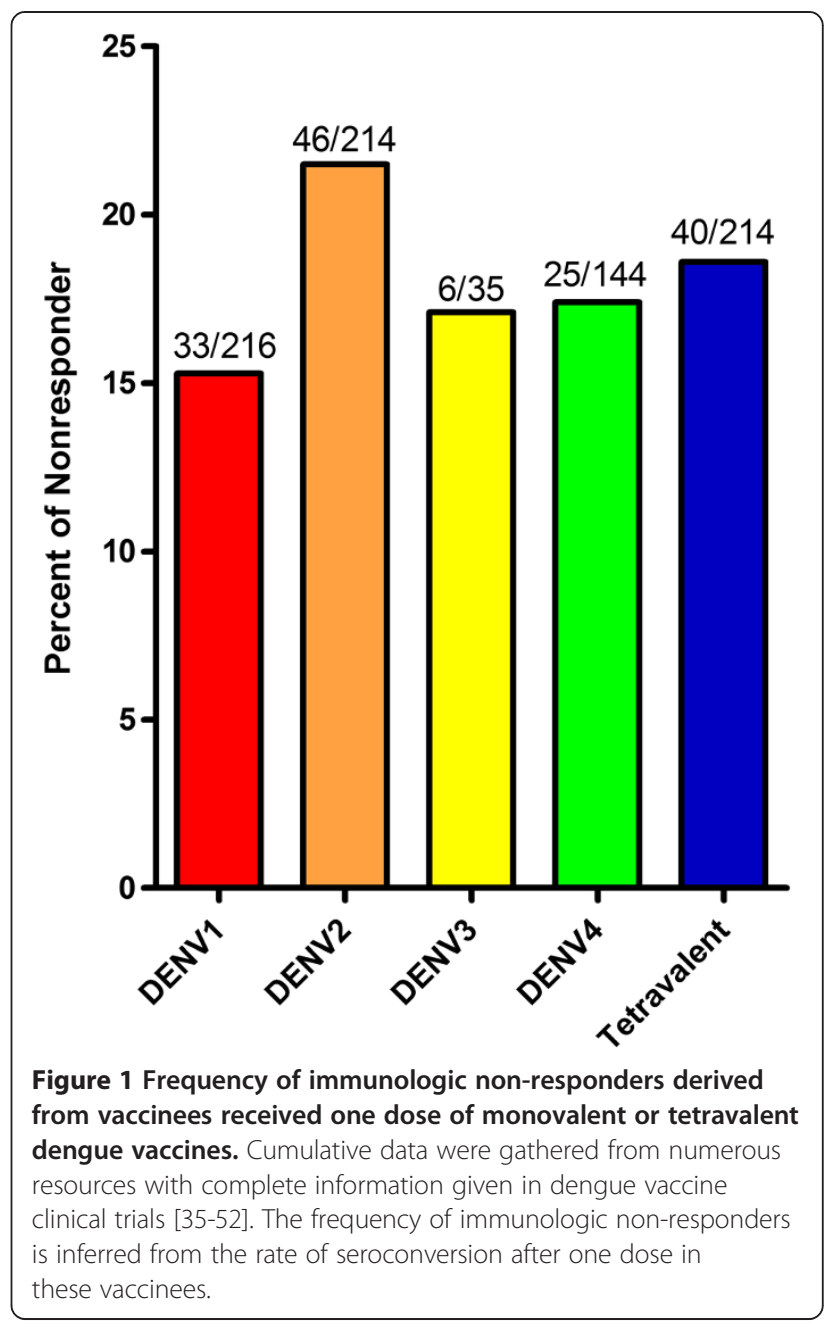

regions indicates that the range is 1 to $10 \%$ among populations in various geographical areas [6,7,20-26]. These data suggest that subjects that are initially immune non-responders may be re-challenged repeatedly with the incoming virus throughout their lives in endemic countries. Interestingly, it has been documented that the frequency of reattack rate in dengue endemic regions or during an outbreak is about 1:20, or $5-8 \%$ [27-32]. Coincidentally, the seroconversion rate in dengue vaccine trials can be up to 90 to $99 \%$ after the $2^{\text {nd }}$ and $3^{\text {rd }}$ dose $[33,34]$. Consequently, several pragmatic questions can be asked; should immunologic non-responders after being re-challenged be defined as primary or secondary infection in dengue endemic regions? Will these non-responders develop severe dengue after repeated exposures with the virus in the natural setting? These questions should be thoughtfully considered and investigated.

One of avenues that can be linked to the immune non-responder is genetic polymorphism in ethnic origin of populations and perhaps in a specific individual. 
In a general term, immune related genetic polymorphisms are much more likely contributing to the phenomena. These include genes for human leukocyte antigens (HLA) or major histocompatibility class, for antibody genes, for cytokines, for Toll-like receptors or receptors in pathogen pattern recognition and others $[53,54]$. Some of these genetic polymorphisms have been associated with quality of immune response and viral disease development, as well as that found in individuals who are hypo- or non-responders to hepatitis $B$ vaccination [55-62]. Recent evidence suggests that defective in antigen intake by the antigen-presenting cells and/or unable to present antigen properly and adequately is not a cause of non-responsiveness to hepatitis B surface antigen from HLA polymorphism [63]. Scientifically, the cascade and complexity of immune responses in pathogen- or vaccine-induced can be highly variable among individuals. Consequently, any genes within the immune response network would potentially contribute to the pleiotropic variation seen in an infected population or vaccinees.

As for how to differentiate the naïve primary infection from hypo/non-responder when no host gene biomarkers are currently available, a number of methods have been proposed. These include a) analysis of an individual's genetic background and HLA typing, b) performing a much more laborious laboratory test such as the identification of a molecular signature using whole genome transcriptional analysis in PBMC [64] or c) the assessment of $\mathrm{CD} 4^{+} \mathrm{T}$ cell subsets, $\mathrm{CD} 31^{\text {+thymic }}$ naïve $\mathrm{CD} 4+\mathrm{T}$ cells, a prognostic marker for immune competence [65]. Thus, in order to further advance the understanding of the pathogenesis of severe dengue, three major categories, naïve primary infection, serologically defined primary infection in endemic zones, and secondary infection, are suggested and should be implemented where it is applicable in the interpretation of results.

The presence of different dengue serotypes and a sub-genotype group within a serotype are the wellestablished complexity in dengue. Each serotype or sub-genotype is capable of inducing typical dengue diseases. Although some sub-genotypes may induce severe dengue more often than others [66,67], dependent upon geographical zones, the concept on the immune nonresponder in dengue endemic regions has not been established in spite of epidemiologically results indicate that repeating exposure with alternate viral serotype correlates with dengue severity [68]. Consequently, in dengue endemic zones, is severe dengue a result of alternate heterologous infection in the prior exposure individual or a non-responder constantly re-challenged by circulating virus remains to be investigated. Currently, there is no assay that can differentiate the sequence of serotype infections in an individual [69]. Therefore, diagnostic tool that can efficiently differentiate the previous infected serotype prior to current other serotype infection is urgently needed.

\section{Conclusion}

The ability to identify and distinguish these 3 categories will shed new light on the development of better diagnostic tools, mitigation of the threat to the blood supply in dengue-endemic countries, and pave a new avenue for molecular processes of immune development in the design and generation of modern vaccines. Furthermore, with a clearer definition of the virus pre-exposure, the search for better diagnostic marker and the identity of the pathogenic cause for severe dengue may be much simpler and faster to reach a consensus which would greatly facilitate the institution of effective and appropriate preventive medicine strategy.

\section{Competing interests}

The authors declare that they have no competing interests.

\section{Authors' contributions}

GCP collected information, designed and organized the structure of the contents and wrote the manuscript. KC reviewed literature, discussed and suggested the contents as well as edited the manuscript. Both authors read and approved the final manuscript.

\section{Acknowledgements}

The authors would like to thank Dr. Aftan A. Ansari, Department of Pathology and Laboratory Medicine, Emory University School of Medicine, for his helpful discussion and suggestions to the manuscript. This study was supported in part by Thailand Research Fund for Senior Research Scholar, and by a startup grant from the National Science Council (NSC99-2321-B006-008) with the Center of Infectious Disease and Signaling Research, NCKU, Taiwan.

\section{Author details}

${ }^{1}$ Department of Microbiology and Immunology, Medical College, National Cheng Kung University, Tainan 70101, Taiwan. ${ }^{2}$ Center of Infectious Disease and Signaling Research, National Cheng Kung University, Tainan 70101,

Taiwan. ${ }^{3}$ Department of Pathology and Laboratory Medicine, Emory Vaccine Center, Emory University School of Medicine, Atlanta, GA 30322, USA. ${ }^{4}$ Department of Pediatrics, Faculty of Medicine Siriraj Hospital, Mahidol University, Bangkok 10700, Thailand.

Received: 28 March 2013 Accepted: 27 May 2013

Published: 31 May 2013

\section{References}

1. Halstead SB, Nimmannitya S, Cohen SN: Observations related to pathogenesis of dengue hemorrhagic fever. IV. Relation of disease severity to antibody response and virus recovered. Yale J Biol Med 1970, 42(5):311-328.

2. Sangkawibha N, Rojanasuphot $S$, Ahandrik S, Viriyapongse S, Jatanasen S, Salitul V, Phanthumachinda B, Halstead SB: Risk factors in dengue shock syndrome: a prospective epidemiologic study in Rayong, Thailand. I. The 1980 outbreak. Am J Epidemiol 1984, 120(5):653-669.

3. Chao DY, Lin TH, Hwang KP, Huang JH, Liu CC, King CC: 1998 dengue hemorrhagic fever epidemic in Taiwan. Emerg Infect Dis 2004, 10(3):552-554.

4. Meltzer E, Schwartz E: A travel medicine view of dengue and dengue hemorrhagic fever. Travel Med Infect Dis 2009, 7(5):278-283.

5. Libraty DH, Acosta LP, Tallo V, Segubre-Mercado E, Bautista A, Potts JA, Jarman RG, Yoon IK, Gibbons RV, Brion JD, Capeding RZ: A prospective 
nested case-control study of Dengue in infants: rethinking and refining the antibody-dependent enhancement dengue hemorrhagic fever model. PLoS Med 2009, 6(10):e1000171.

6. Thai KT, Binh TQ, Giao PT, Phuong HL, le Hung Q, Van Nam N, Nga TT, Groen J, Nagelkerke N, de Vries PJ: Seroprevalence of dengue antibodies, annual incidence and risk factors among children in southern Vietnam. Trop Med Int Health 2005, 10(4):379-386.

7. Balmaseda A, Hammond SN, Perez L, Tellez Y, Saborio SI, Mercado JC, Cuadra R, Rocha J, Perez MA, Silva S, Rocha C, Harris E: Serotype-specific differences in clinical manifestations of dengue. Am J Trop Med Hyg 2006, 74(3):449-456.

8. Stramer SL, Linnen JM, Carrick JM, Foster GA, Krysztof DE, Zou S, Dodd RY, Tirado-Marrero LM, Hunsperger E, Santiago GA, Munoz-Jordan JL, Tomashek KM: Dengue viremia in blood donors identified by RNA and detection of dengue transfusion transmission during the 2007 dengue outbreak in Puerto Rico. Transfusion 2012, 52(8):1657-1666.

9. Petersen LR, Tomashek KM, Biggerstaff BJ: Estimated prevalence of dengue viremia in Puerto Rican blood donations, 1995 through 2010. Transfusion 2012, 52(8):1647-1651.

10. Prince $H E$, Yeh C, Lape-Nixon M: Utility of IgM/lgG ratio and IgG avidity for distinguishing primary and secondary dengue virus infections using sera collected more than 30 days after disease onset. Clin Vaccine Immunol 2011, 18(11):1951-1956.

11. Wilder-Smith A, Chen LH, Massad E, Wilson ME: Threat of dengue to blood safety in dengue-endemic countries. Emerg Infect Dis 2009, 15(1):8-11.

12. Teo D, Ng LC, Lam S: Is dengue a threat to the blood supply? Transfus Med 2009, 19(2):66-77.

13. Dias LL, Amarilla AA, Poloni TR, Covas DT, Aquino VH, Figueiredo LT: Detection of dengue virus in sera of Brazilian blood donors. Transfusion 2012, 52(8):1667-1671.

14. Scott H: A History of Tropical Medicine. Baltimer: The Williams \& Wilkins Company; 1939

15. Chastel C: Eventual role of asymptomatic cases of dengue for the introduction and spread of dengue viruses in non-endemic regions. Front Physiol 2012, 3:70.

16. Jafarzadeh A, Zarei S, Shokri F: Low dose revaccination induces robust protective anti-HBs antibody response in the majority of healthy nonresponder neonates. Vaccine 2008, 26(2):269-276.

17. Hollinger FB: Factors influencing the immune response to hepatitis $B$ vaccine, booster dose guidelines, and vaccine protocol recommendations. Am J Med 1989, 87(3A):36S-40S.

18. Poordad F, Khungar V: Emerging therapeutic options in hepatitis $C$ virus infection. Am J Manag Care 2011, 17(Suppl 4):S123-S130.

19. Pittman PR, Makuch RS, Mangiafico JA, Cannon TL, Gibbs PH, Peters CJ: Long-term duration of detectable neutralizing antibodies after administration of live-attenuated VEE vaccine and following booster vaccination with inactivated VEE vaccine. Vaccine 1996, 14(4):337-343.

20. Graham RR, Juffrie M, Tan R, Hayes CG, Laksono I, Ma'roef C, Erlin, Sutaryo, Porter KR, Halstead SB: A prospective seroepidemiologic study on dengue in children four to nine years of age in Yogyakarta, Indonesia I. studies in 1995-1996. Am J Trop Med Hyg 1999, 61(3):412-419.

21. Wilder-Smith A, Foo W, Earnest A, Sremulanathan S, Paton NI: Seroepidemiology of dengue in the adult population of Singapore. Trop Med Int Health 2004, 9(2):305-308

22. Teixeira MG, Costa MC, Barreto ML, Barreto FR: [Epidemiology of dengue in Salvador-Bahia, 1995-1999]. Rev Soc Bras Med Trop 2001, 34(3):269-274.

23. Yamashiro T, Disla M, Petit A, Taveras D, Castro-Bello M, Lora-Orste M, Vardez S, Cesin AJ, Garcia B, Nishizono A: Seroprevalence of IgG specific for dengue virus among adults and children in Santo Domingo, Dominican Republic. Am J Trop Med Hyg 2004, 71(2):138-143.

24. Iturrino-Monge R, Avila-Aguero ML, Avila-Aguero CR, Moya-Moya T, Canas-Coto A, Camacho-Badilla K, Zambrano-Mora B: Seroprevalence of dengue virus antibodies in asymptomatic Costa Rican children, 2002-2003: a pilot study. Rev Panam Salud Publica 2006, 20(1):39-43.

25. Comach G, Blair PJ, Sierra G, Guzman D, Soler M, de Quintana MC, Bracho-Labadie M, Camacho D, Russell KL, Olson JG, Kochel TJ: Dengue virus infections in a cohort of schoolchildren from Maracay, Venezuela: a 2-year prospective study. Vector Borne Zoonotic Dis 2009, 9(1):87-92.

26. Mohammed H, Tomashek KM, Stramer SL, Hunsperger E: Prevalence of anti-dengue immunoglobulin $\mathrm{G}$ antibodies among American Red Cross blood donors in Puerto Rico, 2006. Transfusion 2012, 52(8):1652-1656.
27. Siler JF, Hall MW, Hitchins AP: Dengue: Its history, epidemiology, mechanism of transmission, etiology, clinical manifestations, immunity and prevention. Philippine J Sci 1926, 29:1-340.

28. Simmons JS, St. John JH, Reynolds FHK: Experimental studies of dengue. Philippine J Sci 1931, 44:1-251.

29. Rice L: Dengue Fever: A clinical report of the Galveston epidemic of 1922. Am J Trop Med Hyg 1923, III(2):73-90.

30. Lane FF: A clinical study of 100 cases of dengue at At. Thomas. US Naval Med Bull 1918, 1(12):615-623.

31. Sharp WB: Immunity in dengue fever. Am J Trop Med Hyg 1934, 15(3):247-264.

32. Shepard DS, Suaya JA, Halstead SB, Nathan MB, Gubler DJ, Mahoney RT, Wang DN, Meltzer Ml: Cost-effectiveness of a pediatric dengue vaccine. Vaccine 2004, 22(9-10):1275-1280

33. Sun W, Eckels KH, Putnak JR, Lyons AG, Thomas SJ, Vaughn DW, Gibbons RV, Fernandez S, Gunther VJ, Mammen MP Jr, Statler JD, Innis BL: Experimental Dengue Virus Challenge of Human Subjects Previously Vaccinated with Live-Attenuated Tetravalent Dengue Virus Vaccines. J Infect Dis 2012, 207(5):700-708.

34. Morrison D, Legg TJ, Billings CW, Forrat R, Yoksan S, Lang J: A novel tetravalent dengue vaccine is well tolerated and immunogenic against all 4 serotypes in flavivirus-naive adults. J Infect Dis 2010, 201(3):370-377.

35. Sun W, Edelman R, Kanesa-Thasan N, Eckels KH, Putnak JR, King AD, Houng HS, Tang D, Scherer JM, Hoke CH Jr, Innis BL: Vaccination of human volunteers with monovalent and tetravalent live-attenuated dengue vaccine candidates. Am J Trop Med Hyg 2003, 69(6 Suppl):24-31.

36. Kanesa-thasan N, Sun W, Kim-Ahn G, Van Albert S, Putnak JR, King A, Raengsakulsrach B, Christ-Schmidt H, Gilson K, Zahradnik JM, Vaughn DW, Innis BL, Saluzzo JF, Hoke CH Jr: Safety and immunogenicity of attenuated dengue virus vaccines (Aventis Pasteur) in human volunteers. Vaccine 2001, 19(23-24):3179-3188.

37. Hoke CH Jr, Malinoski FJ, Eckels KH, Scott RM, Dubois DR, Summers PL, Simms T, Burrous J, Hasty SE, Bancroft WH: Preparation of an attenuated dengue 4 (341750 Carib) virus vaccine. II. Safety and immunogenicity in humans. Am J Trop Med Hyg 1990, 43(2):219-226.

38. Vaughn DW, Hoke CH Jr, Yoksan S, LaChance R, Innis BL, Rice RM, Bhamarapravati N: Testing of a dengue 2 live-attenuated vaccine (strain 16681 PDK 53) in ten American volunteers. Vaccine 1996, 14(4):329-336.

39. Edelman R, Tacket CO, Wasserman SS, Vaughn DW, Eckels KH, Dubois DR, Summers PL, Hoke CH: A live attenuated dengue-1 vaccine candidate (45AZ5) passaged in primary dog kidney cell culture is attenuated and immunogenic for humans. J Infect Dis 1994, 170(6):1448-1455.

40. Innis BL, Eckels KH, Kraiselburd E, Dubois DR, Meadors GF, Gubler DJ, Burke DS, Bancroft WH: Virulence of a live dengue virus vaccine candidate: a possible new marker of dengue virus attenuation. $J$ Infect Dis 1988, 158(4):876-880.

41. Bancroft WH, Top FH Jr, Eckels KH, Anderson JH Jr, McCown JM, Russell PK Dengue-2 vaccine: virological, immunological, and clinical responses of six yellow fever-immune recipients. Infect Immun 1981, 31(2):698-703.

42. Scott RM, Eckels KH, Bancroft WH, Summers PL, McCown JM, Anderson JH, Russell PK: Dengue 2 vaccine: dose response in volunteers in relation to yellow fever immune status. J Infect Dis 1983, 148(6):1055-1060.

43. Bancroft WH, Scott RM, Eckels KH, Hoke CH Jr, Simms TE, Jesrani KD, Summers PL, Dubois DR, Tsoulos D, Russell PK: Dengue virus type 2 vaccine: reactogenicity and immunogenicity in soldiers. J Infect Dis 1984, 149(6):1005-1010.

44. Eckels KH, Scott RM, Bancroft WH, Brown J, Dubois DR, Summers PL, Russell PK, Halstead SB: Selection of attenuated dengue 4 viruses by serial passage in primary kidney cells. V. Human response to immunization with a candidate vaccine prepared in fetal rhesus lung cells. Am J Trop Med Hyg 1984, 33(4):684-689.

45. McKee KT Jr, Bancroft WH, Eckels KH, Redfield RR, Summers PL, Russell PK: Lack of attenuation of a candidate dengue 1 vaccine (45AZ5) in human volunteers. Am J Trop Med Hyg 1987, 36(2):435-442.

46. Durbin AP, McArthur J, Marron JA, Blaney JE Jr, Thumar B, Wanionek K, Murphy BR, Whitehead SS: The live attenuated dengue serotype 1 vaccine rDEN1Delta30 is safe and highly immunogenic in healthy adult volunteers. Hum Vaccin 2006, 2(4):167-173.

47. Durbin AP, McArthur JH, Marron JA, Blaney JE, Thumar B, Wanionek K, Murphy BR, Whitehead SS: rDEN2/4Delta30(ME), a live attenuated 
chimeric dengue serotype 2 vaccine is safe and highly immunogenic in healthy dengue-naive adults. Hum Vaccin 2006, 2(6):255-260

48. Durbin AP, Whitehead SS, McArthur J, Perreault JR, Blaney JE Jr, Thumar B, Murphy BR, Karron RA: rDEN4delta30, a live attenuated dengue virus type 4 vaccine candidate, is safe, immunogenic, and highly infectious in healthy adult volunteers. J Infect Dis 2005, 191(5):710-718.

49. McArthur JH, Durbin AP, Marron JA, Wanionek KA, Thumar B, Pierro DJ Schmidt AC, Blaney JE Jr, Murphy BR, Whitehead SS: Phase I clinical evaluation of rDEN4Delta30-200,201: a live attenuated dengue 4 vaccine candidate designed for decreased hepatotoxicity. Am J Trop Med Hyg 2008, 79(5):678-684

50. Durbin AP, Karron RA, Sun W, Vaughn DW, Reynolds MJ, Perreault JR, Thumar B, Men R, Lai CJ, Elkins WR, Chanock RM, Murphy BR, Whitehead SS: Attenuation and immunogenicity in humans of a live dengue virus type4 vaccine candidate with a 30 nucleotide deletion in its $3^{\prime}$-untranslated region. Am J Trop Med Hyg 2001, 65(5):405-413.

51. Bhamarapravati N, Sutee Y: Live attenuated tetravalent dengue vaccine. Vaccine 2000, 18(Suppl 2):44-47.

52. WHO: Dengue vaccine development: report of the twelfth peer review meeting, 29-31 August 1994. 1995 ed. New Delhi: WHO Regional Office for South-East Asia; 1994

53. Poland GA, Kennedy RB, Ovsyannikova IG: Vaccinomics and personalized vaccinology: is science leading us toward a new path of directed vaccine development and discovery? PLOS Pathog 2011, 7(12):e1002344.

54. Pan LP, Zhang W, Zhang L, Wu XP, Zhu XL, Yan BY, Li JY, Xu AQ, Liu Y, Li H: $C D 3 Z$ genetic polymorphism in immune response to hepatitis $B$ vaccination in two independent Chinese populations. PLoS One 2012, 7(4):e35303.

55. Davila S, Froeling FE, Tan A, Bonnard C, Boland GJ, Snippe H, Hibberd ML, Seielstad M: New genetic associations detected in a host response study to hepatitis B vaccine. Genes Immun 2010, 11(3):232-238

56. Godkin A, Davenport M, Hill AV: Molecular analysis of HLA class II associations with hepatitis $B$ virus clearance and vaccine nonresponsiveness. Hepatology 2005, 41(6):1383-1390.

57. Hohler T, Reuss E, Evers N, Dietrich E, Rittner C, Freitag CM, Vollmar J, Schneider PM, Fimmers R: Differential genetic determination of immune responsiveness to hepatitis $B$ surface antigen and to hepatitis $A$ virus: a vaccination study in twins. Lancet 2002, 360(9338):991-995.

58. McDermott AB, Zuckerman JN, Sabin CA, Marsh SG, Madrigal JA: Contribution of human leukocyte antigens to the antibody response to hepatitis B vaccination. Tissue Antigens 1997, 50(1):8-14.

59. Png E, Thalamuthu A, Ong RT, Snippe H, Boland GJ, Seielstad M: A genome-wide association study of hepatitis $B$ vaccine response in an Indonesian population reveals multiple independent risk variants in the HLA region. Hum Mol Genet 2011, 20(19):3893-3898.

60. Weissman JY, Tsuchiyose MM, Tong MJ, Co R, Chin K, Ettenger RB: Lack of response to recombinant hepatitis $B$ vaccine in nonresponders to the plasma vaccine. JAMA 1988, 260(12):1734-1738.

61. Wang C, Tang J, Song W, Lobashevsky E, Wilson CM, Kaslow RA: HLA and cytokine gene polymorphisms are independently associated with responses to hepatitis B vaccination. Hepatology 2004, 39(4):978-988.

62. Chen J, Liang Z, Lu F, Fang X, Liu S, Zeng Y, Zhu F, Chen X, Shen T, Li J, Zhuang $\mathrm{H}$ : Toll-like receptors and cytokines/cytokine receptors polymorphisms associate with non-response to hepatitis B vaccine. Vaccine 2011, 29(4):706-711.

63. Desombere I, Cao T, Gijbels Y, Leroux-Roels G: Non-responsiveness to hepatitis $B$ surface antigen vaccines is not caused by defective antigen presentation or a lack of B7 co-stimulation. Clin Exp Immunol 2005, 140(1):126-137.

64. Erwin-Cohen R, Porter A, Pittman P, Rossi C, Dasilva L: Host responses to live-attenuated Venezuelan equine encephalitis virus (TC-83): Comparison of naive, vaccine responder and nonresponder to TC-83 challenge in human peripheral blood mononuclear cells. Hum Vacc Immunother 2012, 8(8):1053-1065.

65. Kohler $\mathrm{S}$, Thiel A: Life after the thymus: $\mathrm{CD} 31+$ and $C D 31$ - human naive CD4+ T-cell subsets. Blood 2009, 113(4):769-774.

66. Gubler DJ, Kuno G (Eds): Dengue And Dengue Hemorrhagic Fever, ed First. Wallingford, UK: CABI; 1997
67. Rico-Hesse R: Dengue virus markers of virulence and pathogenicity. Future Virol 2009, 4(6):581.

68. Halstead SB: Dengue. Lancet 2007, 370(9599):1644-1652.

69. Guzman MG, Halstead SB, Artsob H, Buchy P, Farrar J, Gubler DJ, Hunsperger E, Kroeger A, Margolis HS, Martinez E, Nathan MB, Pelegrino JL, Simmons C, Yoksan S, Peeling RW: Dengue: a continuing global threat. Nat Rev Microbiol 2010, 8(12 Suppl):S7-S16

doi:10.1186/1423-0127-20-34

Cite this article as: Perng and Chokephaibulkit: Immunologic hypo- or non-responder in natural dengue virus infection. Journal of Biomedical Science 2013 20:34.

\section{Submit your next manuscript to BioMed Central and take full advantage of:}

- Convenient online submission

- Thorough peer review

- No space constraints or color figure charges

- Immediate publication on acceptance

- Inclusion in PubMed, CAS, Scopus and Google Scholar

- Research which is freely available for redistribution

Submit your manuscript at www.biomedcentral.com/submit
() Biomed Central 